\title{
PROSES PENDAFTARAN TANAH (AJUDIKASI) PADA KANTOR PERTANAHAN DI TINJAU DARI PERATURAN PEMERINTAH NOMOR 24 TAHUN 1997 TENTANG PENDAFTARAN TANAH
}

\author{
Yusman \\ Fakultas Hukum Universitas Pamulang \\ E-mail : yusmangayo@ymail.com
}

\begin{abstract}
Abstrak
Pendaftaran tanah pertama kali dilakukan secara sporadik dan secarasistematik. Pendaftaran tanah bertujuan untuk menjamin dan memberikankepastian hukum terhadap pemilik tanah. Fenomena yang terjadi pada praktekpendaftaran tanah menimbulkan permasalahan bagi pemilik tanah yang akanmelakukan pendaftaran tanah. Peraturan Pemerintah Nomor 24 Tahun 1997 tentang Pendaftaran Tanah Yang dapat dilaksanakan secara sporadik dan secara sistematik memberikan solusi kepada masyarakat untuk dapat menentukan salah satu pilihannya terhadap 2 jenis pendaftaran tanah tersebut.Dalam hal ini diharapkan pemilik tanah dapat memiliki bukti yang kuat terhadap kepemilikan tanahnya. Tujuan dari penelitian ini adalah untuk mengetahui tentang pelaksanaan pendaftaran tanah pertama kali secara sporadik dan cara masyarakat melakukan pendaftaran tanah pertama kali secara sporadik serta untuk mengetahui faktor faktor pendukung dan penghambat dalam pelaksanaan pendaftaran tanah, pelaksanaan pendaftaran tanah pertama kali secara sporadik dapat diajukan oleh pemegang haknya ataupun melalui kuasanya ke Kantor Pertanahan. Sedangkan cara masyarakat dalam melakukan pendaftaran tanah dilakukan secara sporadik dan sistematik. Bagi masyarakatyang melakukan pendaftaran tanah secara sporadik dapat dilakukan secara langsung oleh pemilik tanahnya ataupun melalui Kantor PPAT.
\end{abstract}

Kata Kunci : Pendaftaran Tanah, Panitia.

\begin{abstract}
Land registration is first done sporadically and systematically. Land registration aims to guarantee and provide legal certainty to landowners. The phenomenon that occurs in the practice of land registration causes problems for landowners who will carry out land registration.Government Regulation Number 24 of 1997 concerning Land Registration that can be carried out sporadically and systematically provides solutions to the community to be able to determine one of the options for the two types of land registration. In this case it is expected that landowners can have strong evidence against ownership of the land.The purpose of this research is to find out about the implementation of sporadic land registration for the first time and the way the community
\end{abstract}


first registers land sporadically and to find out the supporting and inhibiting factors in the implementation of land registration, the first sporadic land registration can be submitted by the right holder or through their attorney to the Land Office. Whereas the community's way of registering land is done sporadically and systematically. For people who do sporadic land registration can be done directly by the land owner or through the PPAT Office.

\section{Keywords : Land Registration, Committe}

\section{PENDAHULUAN}

Tanah memiliki peran yang sangat penting artinya dalam kehidupan bangsa Indonesia ataupun dalam pelaksanaan pembangunan nasional yang diselenggarakan sebagai upaya berkelanjutan untuk mewujudkan masyarakat yang adil dan makmur berdasarkan Pancasila dan Undang-Undang Dasar 1945. Oleh karena itu pengaturan penguasaan, pemilikan dan penggunaan tanah perlu lebih diarahkan bagi semakin terjaminnya tertib di bidang hukum pertanahan, administrasi pertanahan, penggunaan tanah, ataupun pemeliharaan tanah dan lingkungan hidup, sehingga adanya kepastian hukum di bidang pertanahan1. Mengingat begitu pentingnya tanah karena dapat menghasilkan sumber daya alam yang sangat bermanfaat bagi orang banyak, maka perlu adanya aturan hukum yang diatur oleh pemerintah. Undang- Undang Dasar 1945 Pasal 33 ayat (3) berbunyi : "Bumi dan air dan kekayaan alam yang terkandung di dalamnya dikuasai oleh negara dan dipergunakan untuk sebesar-besar kemakmuran rakyat". Berdasarkan hak menguasai oleh negara sebagaimana tersebut di atas maka penguasaan atas tanah diatur dalam UUPA (Undang-Undang Nomor 5 tahun 1960 tentang PokokPokok Agraria). Ketentuan tentang kewajiban bagi pemerintah untuk menyelenggarakan pendaftaran tanah diseluruh wilayah Republik Indonesia, yang diatur dalam Pasal 19 Ayat (1) UUPA, yaitu: "Untuk menjamin kepastian hukum oleh Pemerintah diadakan pendaftaran tanah diseluruh wilayah Republik Indonesia menurut ketentuan-ketentuan yang diatur dengan Peraturan Pemerintah."

UUPA juga mengatur kewajiban bagi pemegang Hak Milik, pemegang Hak Guna Usaha,dan pemegang Hak Guna Bangunan untuk mendaftarkan hak atas tanahnya. 
Kewajiban bagi pemegang Hak Milik atas tanah untuk mendaftarkan tanahnya diatur dalam Pasal 23 UUPA, yaitu;

A. Hak Milik, demikian pula setiap peralihan, hapusnya dan pembebanannya dengan hak-hak lain harus didaftarkan menurut ketentuan-ketentuan yang dimaksud dalam pasal 19.

B. Pendaftaran termasud dalam Ayat 1 merupakan alat pembuktian yang kuat mengenai hapusnya hak milik serta sahnya peralihan dan pembebanan hak tersebut.

Mengenai peralihan hak atas tanah, dalam pasal 37 ayat (1) Peraturan Pemerintah Nomor 24 Tahun 1997 tentang pendaftaran tanah menyebutkan bahwa: Tanah merupakan salah satu kebutuhan primer bagi manusia bahkan sampai meninggalpun manusia masih membutuhkan tanah. Kebutuhan manusia terhadap tanah dewasa ini makin meningkat. Hal ini disebabkan semakin bertambahnya jumlah penduduk, sementara disisi lain luas tanah tidak bertambah.

Tanah dalam pengertian yuridis adalah permukaan bumi, hak atas tanah adalah hak atas sebagian tertentu dari permukaan bumi, hak atas tanah adalah hak atas sebagian tertentu di permukaan bumi, yang terbatas, berdimensi dua dengan ukuran panjang dan lebar. Dasar kepastian hukum dalam peraturan-peraturan hukum tertulis sebagai pelaksana Undang-Undang Pokok Agraria No. 5 Tahun 1960, memungkinkan para pihakpihak yang berkepentingan untuk dengan mudah mengetahui hukum yang berlaku dan wewenang serta kewajiban yang ada atas tanah yang dipunyai. Dalam Peraturan Pemerintah No. 24 Tahun 1997 tentang Pendaftaran Tanah Pasal 1 ayat (1) menguraikan yang dimaksud dengan pendaftaran tanah adalah rangkaian kegiatan yang dilakukan oleh pemerintah secara terus menerus, berkesinambungan dan teratur, meliputi pengumpulan, pengelolaan, pembukuan, dan penyajian serta pemeliharaan data fisik dan data yuridis dalam bentuk peta dan daftar, mengenai bidang-bidang tanah dan satuan-satuan rumah susun, termaksud pemberian surat tanda bukti haknya bagi bidang-bidang tanah yang sudah ada haknya dan hak milik atas satuan rumah susun serta hak-hak tertentu yang membebaninya. Pengertian hak milik menurut Henri Lie A. Weng (1970 : 3), Hak milik adalah hak untuk menikmati secara bebas dan memperlakukan secara sesuka si pemilik hak yang sempurna, pemilik dapat menggunakannya, menikmatinya, memusnahkannya, membuangnya, menjualnya. Secara umum pengaturan mengenai hak milik atas tanah 
dalam Undang-Undang Pokok Agraria dapat dilihat dalam Bagian III Bab II Pasal 20 sampai dengan Pasal 27, menurut prinsip-prinsip umum tentang hak milik atas tanah. Hak milik itu berdasarkan Pasal 20 Undang-Undang Pokok Agraria bahwa merupakan hak yang turun temurun, terkuat dan terpenuh yang dapat dipunyai orang atas tanah dan memberi wewenang untuk mempergunakan bagi segala macam keperluan selama waktu yang tidak terbatas sepanjang tidak ada larangan khusus untuk itu. Sifat terkuat dan terpenuhi artinya yang paling kuat dan penuh bagi pemegang hak milik dan mempunyai hak untuk bebas dengan menjual, menghibahkan, menukarkan dan mewariskan. Hak penguasaan atas tanah berisikan serangkaian wewenang, kewajiban dan atau larangan bagi pemegang untuk berbuat atau tidak berbuat sesuatu yang mengenai tanah yang dihakinya, karena telah ditetapkan Undang-Undang Pokok Agraria dan peraturan pemerintah tentang pendaftaran tanah. Pemberian batasan menurut Pasal 4 UndangUndang Pokok Agraria terhadap kepentingan yang langsung berhubungan dengan penggunaan tanah dalam batas-batas menurut peraturan lainnya yang lebih tinggi. Ali Achmad Chomzah (2002 : 11) menyatakan bahwa hukum tanah adalah keseluruhan dari peraturan-peraturan hukum yang mengatur hak dan kewajiban yang bersumber pada hak perseorangan dan badan hukum mengenai tanah yang dikuasainya atau dimilikinya. Dalam rangka memberi kepastian hukum kepada para pemegang hak atas tanah dan diberikan penegasan terhadap kekuatan sertifikat. Dampak arti praktisnya selama belum dibuktikan yang sebaliknya data fisik dan data yuridis dalam perbuatan hukum maupun sengketa didepan pengadilan harus diterima sebagai data yang benar. Individu atau badan hukum lainnya tidak dapat menuntut tanah yang telah bersertifikat atas nama orang lain atau badan hukum lainnya. Pelaksanaan untuk tercapainya jaminan dan kepastian hukum hak-hak atas tanah diselenggarakan pendaftaran tanah dengan mengadakan pengukuran, pemetaan tanah dan penyelenggaraan tata usaha hak atas tanah merupakan hubungan hukum orang atau badan hukum dengan sesuatu benda yang menimbulkan kewenangan atas obyek bidang tanah dan memaksa orang lain untuk menghormatinya akibat dari pemilikan. Pasal 19 Undang-Undang Pokok Agraria menugaskan kepada pemerintah untuk menyelenggarakan pendaftaran tanah yang bersifat rechts. Pendaftaran tanah berfungsi untuk mengetahui status bidang tanah, siapa pemiliknya, apa haknya, berapa luasnya, untuk apa dipergunakan. Untuk memperoleh kekuatan hukum rangkaian 
kegiatan pendaftaran tanah secara sistematis, pengajuan kebenaran materiil pembuktian data fisik dan data yuridis hak atas tanah, ataupun lain hal yang dibutuhkan sebagai dasar hak pendaftaran tanah, dan atau riwayat asal usul pemilikan atas tanah, jual-beli, warisan, tidak terlepas pada peraturan perundang-undangan yang berlaku. Pendaftaran tanah yang dilakukan secara sistematis sampai saat ini masih dianggap belum maksimal dan prosedural dalam masyarakat, walaupun sebelum dilakukan pengukuran oleh tim teknis telah dilakukan pematokan awal oleh para pemilik tanah. Masyarakat Kelurahan Buaran butuh pengakuan atas kepemilikan tanah tersebut. Peranan dari Kantor Badan Pertanahan Nasional (BPN) dalam melakukan pendaftaran tanah sangat dibutuhkan mulai dari tahap permohonan pendaftaran tanah oleh pihak yang berhak atas tanah atau yang dikuasainya diperlukan peran aktif dan ketelitian dari pihak BPN sebagai penyelenggara pendaftaran tanah yang dalam pelaksanaannya dilakukan oleh kantor pertanahan. Berbagai masalah yang muncul seperti adanya, penyerobotan lahan yang diikuti dengan tindakan penertiban sertifikat oleh pihak yang tidak berhak merupakan beberapa masalah pertanahan yang kerap muncul di masyarakat berkaitan dengan kegiatan pendaftaran tanah, dimana hal tersebut di sebabkan antara lain oleh ketidaktahuan masyarakat tentang obyek tanah yang ternyata telah memiliki sertifikat, kembali dimohonkan untuk diterbitkan sertifikatnya lagi (satu obyek tanah memiliki dua sertifikat). Hal ini terjadi karena masalah terbatasnya pengumuman kepada masyarakat oleh pihak BPN dari proses pendataan data fisik dan data yuridis sampai dengan penerbitan sertifikat. Proses sertifikat tanah merupakan sebuah proses sistematis dimana proses ajudikasi yang merupakan kegiatan yang dilaksanakan dalam rangka proses pendaftaran tanah untuk pertama kali, meliputi pengumpulan dan penetapan kebenaran data fisik dan data yuridis mengenai satu atau beberapa obyek pendaftaran tanah untuk keperluan pendaftarannya adalah salah satu proses di dalamnya, ketika dalam proses ajudikasi terdapat masalah dalam penanganannya, seperti adanya ketidak akuratan baik itu data fisik ataupun data yuridis maka akan mengganggu secara keseluruhan proses pensertifikatan tanah. Proses ajudikasi yang merupakan kegiatan dilaksanakan dalam rangka proses pendaftaran tanah untuk pertama kali, meliputi pengumpulan dan penetapan kebenaran data fisik dan data yuridis mengenai satu atau beberapa obyek pendaftaran tanah untuk keperluan pendaftarannya, tentunya menarik perhatian terhadap kasus-kasus yang masalahnya adalah sertifikat 
ganda, dimana ketika sebuah proses pendaftaran tanah telah dilakukan sesuai dengan prosedur tentunya tidak akan terjadi permasalahan. Berdasarkan hal tersebut di atas, maka penulis tertarik untuk melakukan kajian secara ilmiah tentang "Proses

Pendaftaran Tanah (Ajudikasi) Berdasarkan Peraturan Pemerintah Nomor. 24

\section{Tahun 1997 Tentang Pendaftaran Tanah”.}

\section{Konsep Hak Atas Tanah}

a. Pengertian Hak Milik

Hak-hak atas tanah berdasarkan Pasal 16 ayat (1) UUPA terdiri atas :

1) Hak milik

2) Hak guna usaha

3) Hak guna bangunan

4) Hak pakai

5) Hak sewa

6) Hak membuka tanah

7) Hak memungut hasil hutan

8) Hak-hak lain yang tidak masuk dalam pembagian hak tersebut dan akan ditetapkan dengan undang-undang.

Soedharyo Soimin (2001:1) menyatakan bahwa, bila dilihat dari kepentingan yang mendesak dan sangat dibutuhkan oleh manusia ataupun badan hukum maka hak atas tanah dapat dibedakan atas hak milik, hak pakai, hak guna bangunan dan hak guna usaha.

Senada dengan pendapat tersebut A P Perlindungan (1998: 13), menyatakan bahwa :

"Pada dasarnya hak atas tanah hanya terdiri atas hak milik, hak guna usaha, hak guna bangunan dan hak pakai. Namun berdasarkan UUPA maka hak tersebut dapat ditambah dengan hak memungut hasil dan hak membuka tanah”.

Salah satu hak atas tanah yang sering menjadi pangkal sengketa di pengadilan adalah sengketa terhadap hak milik atas tanah. Secara yuridis hak milik diatur dalam Pasal 20 ayat (1) \& (2) UUPA yang menegaskan bahwa, hak milik adalah hak turun temurun, terkuat dan terpenuh yang dapat dipunyai orang atas 
tanah dengan mengingat ketentuan dalam Pasal 6 UUPA, dan hak ini dapat beralih serta dialihkan pada pihak lain.

Sehubungan dengan pengertian tersebut Soedharyo Soimin (1993: 1) mengatakan bahwa, hak milik adalah hak yang dapat diwariskan secara turun temurun, secara terus menerus dengan tidak harus memohon haknya kembali apabila terjadi pemindahan hak. Selanjutnya A. P. Parlindungan (1998: 137) menegaskan bahwa, unsur-unsur dari hak milik :

1) Turun temurun

Bahwa hak milik dapat diwariskan pada pihak lain atau ahli waris apabila pemiliknya meninggal dunia tanpa harus memohon kembali bagi ahli waris untuk mendapatkan penetapan.

2) Terkuat dan terpenuh Hal ini berarti bahwa hak milik merupakan hak yang terkuat dan terpenuh yang dimiliki oleh seseorang dapat dibedakan dengan hak yang lain seperti hak guna usaha, hak guna bangunan dan hak pakai, bahwa diantara hak-hak atas tanah hak miliknya yang mutlak, tak terbatas dan tidak dapat diganggu gugat, tetapi tetap mempunyai fungsi sosial.

3) Fungsi sosial

Maksudnya adalah meskipun hak milik sifatnya terkuat dan terpenuh tetapi tetap mempunyai fungsi sosial, yang mana apabila hak ini dibutuhkan untuk kepentingan umum maka pemiliknya harus menyerahkannya pada negara dengan mendapatkan ganti rugi yang layak.

4) Dapat beralih dan dialihkan

Hak milik dapat dialihkan pada pihak yang lain sesuai dengan peraturan perundang-undangan yang berlaku baik melalui penjualan, penyerahan, hibah atau bahkan melalui hak tanggungan.

Apabila disimak bunyi Pasal 21 ayat (1),(2) dan (3) UUPA maka dapat diketahui bahwa yang berhak untuk memperoleh hak milik adalah hanya warga negara Indonesia; oleh pemerintah ditetapkan badan-badan hukum yang dapat mempunyai hak milik dengan syarat-syarat yang telah ditetapkan; orang asing yang 
sudah berlakunya undang-undang ini memperoleh hak milik karena pewarisan tanpa wasiat atau pencampuran harta kekayaan.

\section{METODE PENELITIAN}

Penelitian ini menggunakan Metode penelitian normatif empiris. Metode penelitian normatif merupakan model penelitian yang menekankan pada kajian ilmu hukum dan berusaha menekankan pada kaidah-kaidah hukum yang berlaku sehubungan dengan kedudukan tanah Di samping itu penelitian empiris adalah kajian ilmu hukum untuk menemukan/ menganalisis kenyataan-kenyataan yang terjadi di dalam masyarakat khususnya di Kelurahan Buaran Tangerang selatan.

\section{HASIL PENELITIAN DAN ANALISIS}

Pengertian pendaftaran tanah menurut Pasal 1 Peraturan Pemerintah (PP) Nomor 24 Tahun 1997 tentang Pendaftaran Tanah adalah rangkaian kegiatan yang dilakukan oleh pemerintah secara terus menerus berkesinambungan dan teratur meliputi pengumpulan, pengelolaan, pembukuan dan penyajian serta pemeliharaan data fisik dan yuridis, dalam bentuk peta dan daftar mengenai bidang-bidang tanah dan satuan-satuan rumah susun termaksud pemberian sertifikat, sebagai surat tanda bukti hanya bidangbidang tanah yang sudah ada haknya dan hak milik atas satuan rumah susun termasuk pemberian sertifikat sebagai surat tanda bukti haknya bagi bidang-bidang tanah yang sudah ada haknya dan hak milik atas satuan rumah susun serta hak-hak tertentu yang membebaninya.

Pendaftaran tanah adalah suatu rangkaian kegiatan, yang dilakukan oleh Negara/ Pemerintah secara terus menerus dan teratur, berupa pengumpulan keterangan atau data tertentu mengenai tanah-tanah tertentu yang ada di wilayah-wilayah tertentu, pengolahan, penyimpanan dan penyajiannya bagi kepentingan rakyat, dalam rangka memberikan jaminan kepastian hukum di bidang pertanahan, termasuk penerbitan tanda buktinya dan pemeliharaannya. (Budi Harsono, 2003:73) Kata-kata "suatu rangkaian kegiatan" menunjuk kepada adanya berbagai kegiatan dalam penyelenggaraan pendaftaran tanah, yang berkaitan satu dengan yang lain, berturutan menjadi satu kesatuan rangkaian yang bermuara pada tersedianya data yang diperlukan dalam rangka memberikan jaminan 
kepastian hukum dibidang pertanahan bagi rakyat. Kata "terus menerus" menunjuk kepada pelaksanaan kegiatan, yang sekali dimulai tidak akan ada akhirnya. Data yang sudah terkumpul dan tersedia harus selalu dipelihara, dalam arti disesuaikan dengan perubahan perubahan yang terjadi kemudian, hingga tetap sesuai dengan keadaan terakhir. Kata "teratur" menunjukan, bahwa semua kegiatan harus berlandaskan peraturan perundang-undangan yang sesuai, karena hasilnya akan merupakan data bukti menurut hukum, biarpun daya kekuatan pembuktiannya tidak selalu sama dalam hukum negara-negara yang menyelenggarakan pendaftaran tanah.(Budi Harsono, 2003:73).

\section{PENUTUP}

\section{A. Kesimpulan}

1. Proses pendaftaran tanah yang dilakukan oleh pihak Kantor Pertanahan Kota Tangerang Selatan (Panitia Ajudikasi) telah dilakukan sesuai dengan prosedur yang diamanatkan dalam Peraturan Pemerintah No 24 Tahun 1997 tentang Pendaftaran Tanah.

2. Faktor - faktor yang menghambat proses pendaftaran tanah ialah kesalahan informasi, adanya sanggahan/keberatan dari pihak lain, dan penggunaan jasa orang lain dalam pengurusan pendaftaran tanah.

\section{B. Saran}

1. Agar pihak Kantor Pertanahan Kota Tangerang Selatan dapat meningkatkan jumlah tanah yang menjadi prioritas dalam pendaftaran tanah (ajudikasi).

2. Agar pihak Kantor Pertanahan Kota Tangerang Selatan dalam melakukan proses pendaftaran tanah (ajudikasi) senantiasa memperhatikan kelengkapan informasi dan data yang diberikan pemohon. 


\section{DAFTAR PUSTAKA}

\section{Buku :}

A.P.Parlindungan, 1999, "Pendaftaran Tanah Indonesia (Berdasarkan P.P. No. 24 Tahun 1997 Dilengkapi dengan Peraturan Jabatan Pejabat Pembuat Akta Tanah (P.P. No.37 Tahun 1998)”, CV. Mandar Maju, Bandung.

AchmadRubaie, 2007,“HukumPengadaan Tanah Untuk Kepentingan Umum”, Bayumedia, Malang.

Adrian Sutedi, 2010, Peralihan Hak atas Tanah dan Pendaftarannya, Cet. 4, Sinar Grafika, Jakarta.

Bachtiar Effendi, 1993, "Kumpulan Tulisan Tentang Hukum Tanah", Alumni, Bandung.

, 1993, Pendaftaran Tanah di Indonesia dan Peraturan Pelaksanaannya, Alumni, Bandung.

BoediHarsono,1978, “Beberapa Analisis Tentang Hukum Agraria”, Penerbit Esa Studi Klub, Jakarta.

,1999, "Hukum Agraria Indonesia : Sejarah Pembentukan UUPA, Isi dan Pelaksanannya”, Jilid 1, Djambatan, Jakarta.

,2003, "Hukum Agraria Indonesia: SejarahPembentukanUndangUndangPokokAgraria : Isi danPelaksanaan”, Djambatan, Jakarta.

,2005, Hukum Agraria Indonesia: Sejarah Pembentukan Undang- Undang Pokok Agraria, Isi dan Pelaksanannya, Ed. Rev., Cet. 10, Djambatan, Jakarta.

,2008, "Hukum Agraria Indonesia, Himpunan Peraturan-Peraturan Hukum Tanah”, Djambatan, Jakarta. 
Cholid Narbuko, 2004, "Metode Penelitian Kualitatif”, Remaja Rosdakarya, Bandung.

CST. Kansil, 1986, Pengantar Ilmu Hukum dan Tata Hukum Indonesia, Balai Pustaka, Jakarta.

Dendy Sugono, dkk, 2008, “Kamus Bahasa Indonesia”, Pusat Bahasa, Departemen Pendidikan Nasional, Jakarta.

Departemen Pendidikan Nasional, 2002, Kamus Besar Bahasa Indonesia, Edisi Ketiga, Balai Pustaka, Jakarta.

Djojodirdjo, M.A. Moegni, 1979, "Perbuatan Melawan Hukum : Tanggung Gugat(Aansprakelijkheid) Untuk Kerugian, Yang Disebabkan Karena Perbuatan Melawan Hukum”, Pradnya Paramita, Jakarta.

Eddy Ruchiyat, 1998, "Sistem Pendaftaran Tanah Sebelum dan Sesudah Berlakunya UUPA”, Armico, Bandung.

Effendi Perangin, 1986, "Pertanyaan dan Jawaban Tentang Hukum Agraria", Rajawali, Jakarta.

Esmi Warassih Pujirahayu, 1981, Hukum Dalam Perspektif Sosial, Peyunting Satjipto Rahardjo, Alumni, Bandung.

Herlien Budiono, 2007, Kumpulan Tulisan Hukum Perdata di Bidang Kenotariatan, PT. Citra Aditya Bakti, Bandung.

Irawan Soehartono, 1999, "Metode Penelitian Sosial Suatu Tehnik Penelitian Bidang Kesejahteraan Sosial Lainnya”, Remaja Rosda Karya, Bandung.

Irawan Soerodjo, 2003, “Kepastian Hukum Hak Atas Tanah Di Indonesia”, Arloka, Surabaya.

Irene Eka Sihombing, 2005, "Segi-segi Hukum Tanah Nasional dalam Pengadaan Tanah Untuk Pembangunan”, Cet I, Universitas Trisakti, Jakarta. 
JJ. M. Wuisman, 1996, “Penelitian Ilmu-ilmu Sosial, Asas-Asas”, Penyunting M. Hisyam, Fakultas Ekonomi Universitas Indonesia, Jakarta.

Kartono, 1982, Persetujuan Jual Beli Menurut Kitab Undang-undang Hukum Perdata, Cetakan 2, Pradnyana Paramita, Jakarta.

Khairunnisa, 2008, “Kedudukan, Peran dan Tanggung Jawab Hukum Direksi”,Pasca Sarjana,USU, Medan.

Komariah, 2001, “Hukum Perdata”, Edisi Revisi, Universitas Muhammadiyah Malang, Malang.

Lexy J. Moleong, 1993, “Metodologi Penelitian Kualitatif”, Remaja Rosdakarya, Bandung.

M. Solly Lubis, 1994, “Filsafat Ilmu dan Penelitian”, Mandar Madju, Bandung. Nasution S, 1992, “Metode Penelitian Kualitatif”, Tarsito, Bandung.

Peter Mahmud Marzuki, 2008, "Penelitian Hukum”, KencanaPrenada Media, Jakarta.

R. Subekti, 1975, Hukum Pembuktian, Pradnya Paramita, Jakarta. dan Tjitrosudibio, 2001, Kilab Undang-undang Hukum Perdata, Pradnya Paramita, Jakarta.

Ridwan H.R., 2006, Hukum Administrasi Negara, Raja Grafindo Persada, Jakarta.

Robert Siedman dalam Nurul Akhmad, 2009, Interasi Politik Dalam Proses Pembentukan Hukum, Orasi Ilmiah, Dies Natalis Fakultas Hukum UNNES, Semarang.

Ronny Hanitijo Soemitro, 1990, "Metodologi Penelitian Hukum dan Yurimetri”, Ghalia Indonesia, Jakarta.

Roscoe Pound. "Introduction To The Phlisophy Of Law" dalam Romli Atmasasmita, 2000, “Perbandingan Hukum Pidana”, Cet.II, Mandar Maju, Bandung. 
Satjipto Rahardjo, 1980, Hukum dan Masyarakat, Angkasa, Bandung. ,1996, “Ilmu Hukum”, PT. Citra Aditya Bakti, Bandung.

Shidarta, 2006, Hukum Perlindungan Konsumen Indonesia, Edisi Revisi, Gramedia Widiasarana Indonesia, Jakarta.

Soerjono Soekanto, 2007, “Pengantar Penelitian Hukum”, UI Press, Jakarta.

Sonny Darsanto, 2009, “Tinjauan Yuridis Pelaksanaan Sita Jaminan (Conservatoir Beslag) Terhadap Tanah Sebagai Objek Jual Beli Akta PPAT, (Studi Kasus Putusan No. 54 / Pdt / G / 1999 / PN.Pt di Pengadilan Negeri Pati)”, Tesis, Program Studi Magister Kenotariatan Program Pasca Sarjana Universitas Diponegoro, Semarang.

Sri Winarsi, "PengaturanNotarisdan PPAT sebagaiPejabatUmum”, MajalahYuridika, FakultasHukumUniversitasAirlangga, Volume 17 No.2, Surabaya, Maret, 2002.

Sudikno Mertokusumo, 1991, “Mengenai Hukum (Suatu Pengantar)”, Liberty, Yogyakarta.

Sugiono, 2007, "Metodologi Penelitian Pendidikan”, Alfabeta. Bandung, 2007, hal.194.

Teguh Prasetyo dan Abdul Hakim Barkatullah, tanpa tahun, "Politik Hukum Pidana Kajian Kebijakan Kriminalisasai dan Deskriminalisasi”, Pustaka Pelajar, Yogyakarta.

Urip Santoso, 2010, Pendaftaran dan Peralihan Hak atas Tanah, Cet. 2, Kencana, Jakarta.

W.J.S. Poerwadarminta, 2003, “Kamus Umum Bahasa Indonesia”, Balai Pustaka, Jakarta.

Winarno Surachmad, 2000, “Pengertian Metodologi Ilmiah”, CV Tarsito, Bandung. 


\section{Peraturan Per Undang-Undangan :}

Undang-Undang Dasar Negara Republik Indonesia 1945.

Undang-Undang Nomor 5 Tahun 1960 tentasng Peratauran Dasar Pokok- pokok Agraria.

Peraturan Pemerintah Nomor 24 Tahun 1997 tentang Pendaftaran Tanah.

Peraturan Pemerintah Nomor 37 Tahun 1998 tentang Peraturan Jabatan Pejabat Pembuat Akta Tanah.

Peraturan Kepala Badan Pertanahan Nasional Nomor 3 Tahun 1997 tentang Ketentuan Pelaksanaan Peraturan Pemerintah Nomor 24 Tahun 1997 Tentang Pendaftaran Tanah.

Peraturan Kepala Badan Pertanahan Nasional Nomor 1 Tahun 2006 tentang Ketentuan Pelaksanaan Peraturan Pemerintah Nomor 37 Tahun 1998 Tentang Peraturan Jabatan Pejabat Pembuat Akta Tanah.

Peraturan Kepala Badan Pertanahan Nasional Nomor 23 Tahun 2009 tentang Perubahan Atas Peraturan Kepala Badan Pertanahan Nasional Nomor 1 Tahun 2006 Tentang Ketentuan Pelaksanaan Peraturan Pemerintah Nomor 37 Tahun 1998 Tentang Peraturan Jabatan Pejabat Pembuat Akta Tanah.

Peraturan Kepala Badan Pertanahan Nasional Nomor 8 Tahun 2012 tentang Perubahan Atas Peraturan Kepala Badan Pertanahan Nasional Nomor 3 Tahun 1997 Tentang Ketentuan Pelaksanaan Peraturan Pemerintah Nomor 24 Tahun 1997 Tentang Pendaftaran Tanah. 